University of Nebraska - Lincoln

DigitalCommons@University of Nebraska - Lincoln

USDA National Wildlife Research Center - Staff

Publications

U.S. Department of Agriculture: Animal and Plant Health Inspection Service

2009

Sapro-Zoonotic Risks Posed by Wild Birds in Agricultural

Landscapes

Larry Clark

USDA/APHIS/WS National Wildlife Research Center, larry.clark@aphis.usda.gov

Follow this and additional works at: https://digitalcommons.unl.edu/icwdm_usdanwrc

Part of the Environmental Sciences Commons

Clark, Larry, "Sapro-Zoonotic Risks Posed by Wild Birds in Agricultural Landscapes" (2009). USDA National Wildlife Research Center - Staff Publications. 877.

https://digitalcommons.unl.edu/icwdm_usdanwrc/877

This Article is brought to you for free and open access by the U.S. Department of Agriculture: Animal and Plant Health Inspection Service at DigitalCommons@University of Nebraska - Lincoln. It has been accepted for inclusion in USDA National Wildlife Research Center - Staff Publications by an authorized administrator of DigitalCommons@University of Nebraska - Lincoln. 


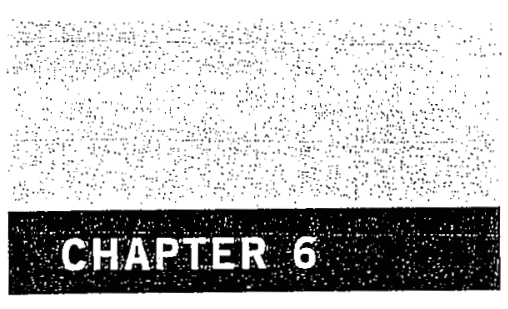

\title{
Sapro-Zoonotic Risks Posed by Wild Birds in Agricultural Landscapes
}

\author{
Larry Clark \\ United States Department of Agriculture, Animal and Plant Health Inspection Service,
} National Wildlife Research Center, Fort Collins, CO

\section{CHAPTER GONMNIS}

Introduction

Bird Species Commonly Associated with Agriculture

Pigeons

Gulls

Water Fowl

123

Passerines

Bacterial Diseases

Campylobacter

Chlamydia

Escherichia coli

Listeria

Salmonella

Fungal Diseases

Aspergillus

128

Cryptococcus

128

Histoplasma

129

130

Parasitic Diseases

Cryptosporidia

130

Microsporidia

130

Toxoplasma

131

Mitigation Options

Summary 


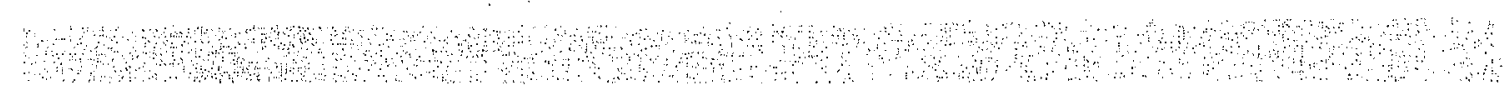

\section{INTRODUCTION}

There are over 1400 catalogued human pathogens, with approximately $62 \%$ classified as zoonotic (Taylor et al., 2001). Most evidence of direct transmission of pathogens to humans involves domestic and companion animals, whereas the reservoir for most zoonoses is wildlife; yet there are relatively few well-documented cases for the direct involvment of transmission from wildlife to humans (Kruse et al., 2004). In part, this absence of evidence reflects the mobility of wildlife, the difficulty in accessing relevant samples, and the smaller number of studies focused on characterizing wildlife pathogens relative to the human and veterinary literature (McDiarmid, 1969; Davis et al., 1971; Hubalek, 2004). Because humans generally do not have direct contact with wild birds, exposure to pathogens is via indirect routes, that is, environmental. This indirect exposure route (sapro-zoonotic) makes identifying the wild bird source of the pathogen all the more difficult. However, with better diagnostic technologies and better understanding of the disease ecology, documenting the risks posed by wildlife to human health become more feasible.

This review focuses on the risks wild birds pose to the contamination of field crops and the risk such contamination poses to human health. For the most part, there are few studies that document the role wild birds have in contaminating field crops and subsequent acquisition of pathogens and onset of disease by humans (Tsiodras et al., 2008). Most of the evidence in the literature focuses on relatively few commensal wild life species in urbanized environments, or at best, general wildlife surveillance and monitoring efforts. Absent any compelling direct evidence, this review summarizes the circumstantial evidence, relying mostly on the characterization of host range of pathogens, similarities of virulence traits of animal and human pathogens, and habitat use patterns of wild birds in agricultural and urban landscapes. Nonetheless, the material presented here does represent a solid circumstantial case for the potential of wild birds to contaminate the field and to act as agents for the transmission of pathogens to humans. More directed studies will be needed to form a more informed assessment as to what actual human pathogen contamination risks wild birds pose to field crops, and by implication, to human health. Finally, this review briefly covers mitigation efforts that might be undertaken to reduce risks of pathogen transmission by wild birds.

\section{BIRD SPECIES COMMONLY ASSOCIATED WITH AGRICULTURE}

Wild birds, and especially migratory species, can become long-distance vectors for a wide range of microorganisms. Moreover, many bird species incorporate agricultural fields into their habitat use patterns. However, for 
the purpose of this review, focus is limited to only a few groups of birds: gulls (Charadriformes), water fowl (Anseriformes), pigeons and doves (Columbiformes), and selected passerine birds (Passeriformes) such as blackbirds, crows, starlings, and sparrows. These groups of birds tend to have high-use patterns of agricultural habitats, they are abundant, and they have close commensal relationships with human activity. These species also tend to be abundant and gregarious; hence, they provide greater opportunity and capacity to contribute larger fecal loads to the environments they use. In the end, it is the likelihood and magnitude for fecal contamination of soils, substrates, and water that represents the most direct link to risks to human health.

Contamination of produce can occur via many routes; for example, at the field level during the growing season, during harvesting, postharvest handling, processing, shipping, marketing, or in the home (Beuchat and Ryu, 1997). Wild birds are most likely to be involved in contamination while the crops are in the field, and perhaps at field-side processing and storage facilities. Moreover, the likelihood that birds are responsible for contamination of crops with human pathogens will depend largely on the birds' exposure to environmental sources of pathogens (Figure 6.1), their capacity to physically transport the pathogen, and perhaps but not necessarily be limited by their ability to act as a reservoir of the pathogen (Kruse et al., 2004).

\section{Pigeons}

Pigeons (Colnmba livia) live in close association with humans (Johnston and Janiga, 1995). They are a gregarious species that feed in flocks, form large roosts, and visit habitats that have a high likelihood of harboring human pathogens (e.g., dairies and feedlots). Pigeons will often flock to agricultural fields to pick up grit to aid in digestion, or to consume spilled grains. As with most commensal bird species considered to be at high risk for transmission of human pathogens, pigeons have a prodigious capacity to produce feces. When occurring in large numbers, the fecal load for contamination of surface water and soils can also be large. Perhaps more importantly, is the propensity of pigeons to use architectural structures as day and night roosting sites. Open crop storage or processing sheds present an ideal condition for attracting pigeons, and in the absence of bird exclusionary mitigation measures, present an opportunity for fecal accumulation. As with most species of birds, humans are not likely to come in direct contact with pigeons; rather humans are likely to come in contact with feces or fecally contaminated substrates. Accumulation of feces presents greater opportunities for direct contact of produce being processed or stored with contaminated soils, feces, dusts, and water sources (Figure 6.1). 


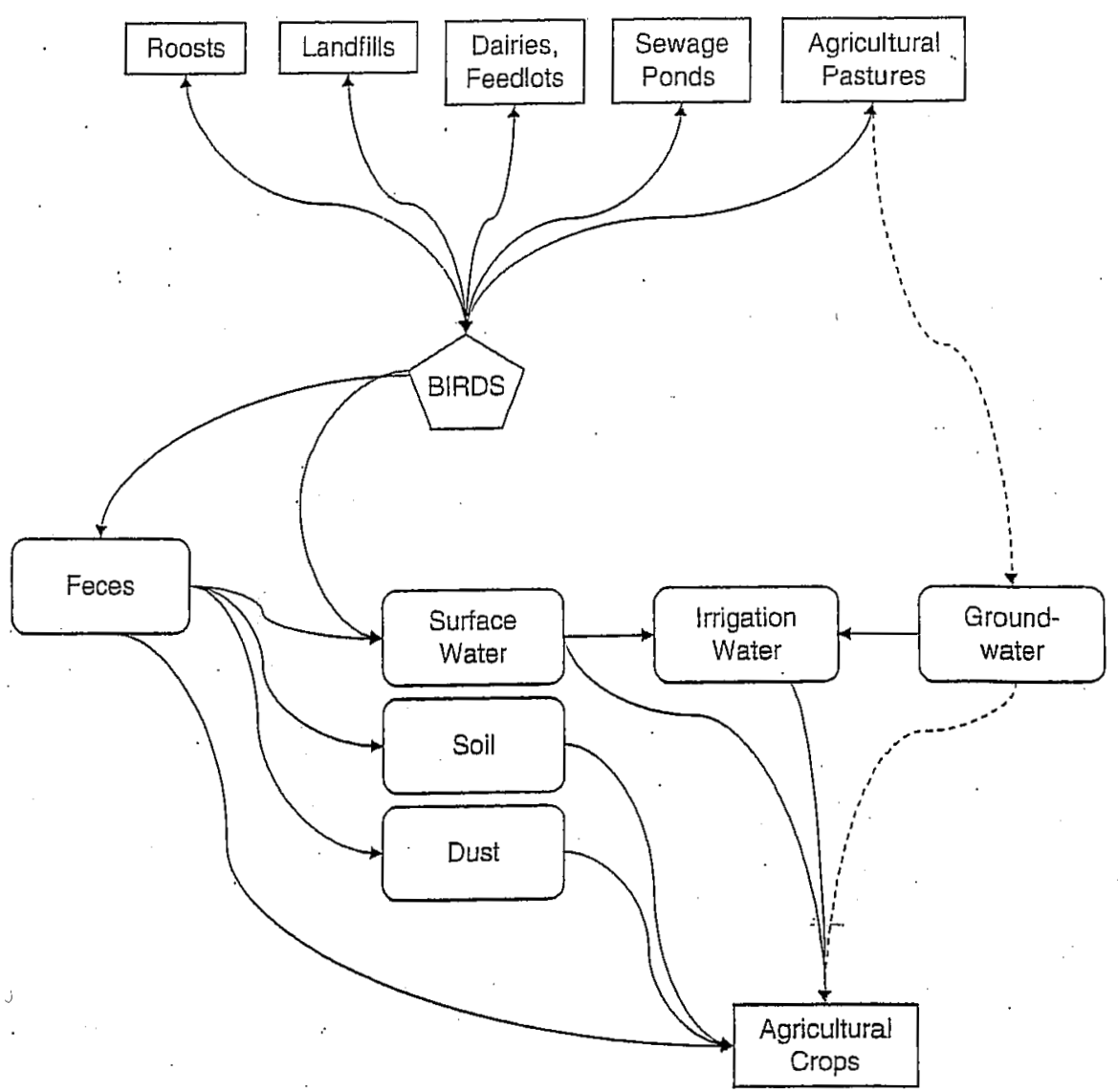

FIGURE 6.1 Possible routes of contamination of field or orchard crops by wild birds. Rectangles indicate environmental sources/habitats of pathogens. Pentagon represents various species of wild birds likely to visit both the source and agricultural landscapes. Rounded rectangles represent.media in which pathogens may reside and be transported.

Over 60 human pathogens have been isolated from pigeons; however, only five pathogens have been documented to be routinely transmitted to humans (Haag-Wackernagel and Moch, 2004): Chlamydophila psittaci, Histoplasma capsulatum, Aspergillus spp., Candida parapsilosis, and Cryptococcus neoformans. Most cases of disease transmission are related to inhalation of dusts and aerosols (Anon., 2002), emphasizing the risk to human health of accumulated feces at building structures. Only one case of foodborne illness has been linled directly to pigeons, and that was a case of lemon pudding made from the eggs of domestic pigeons (Clarenburg and Dornicixx, 1933). 


\section{Gulls}

A variety of species of gulls (Laridae) have been implicated in the carriage of human pathogens and contamination of watersheds, surface waters, and structures (Wither et al., 2005; Kinzelman et al., 2008). For the most part the number of gulls is increasing, largely owing to the availability of landfills, which provide a source of abundant food. Gulls are attracted to agricultural fields to forage on rodents, insects, and at times the crops themselves (O'Connor, 1992). Gulls can occur in large numbers, produce prodigious quantities of fecal material, and thus act as a source for contamination of soils and substrates. Gulls frequent landfills, dairies, feedlots, sewage ponds, other waste facilities, and agricultural pastures, all sources of human pathogens (Coulson et al., 1983; Fricker, 1984; Yorio and Caille, 2004; Nelson et al., 2008).

\section{Water Fowl}

Ducks and geese frequent agricultural fields to feed on crops, spilled grains, acquire grit, or loaf. Water fowl are most likely to be a source of contamination of soils and surface waters, and indirectly, groundwater (Somarelli et al., 2007; Graczyk et al., 2008). Large flocks are likely to frequent agricultural fields beginning in the fall and leaving in the early spring (McKay et al., 2006; Amano et al., 2007). During this period the flocks may move across. the landscape on a local, regional, or continental scale, thus increasing the opportunities for transporting pathogens from one site to another. Water fowl are lizely to use surface water areas, agricultural pastures, and sewage ponds, all of which can act as environmental sources for human pathogens (Conn et al., 2007).

\section{Passerines}

The numbers of passerine species that use agricultural fields is large, but those that travel in large flocks are more limited. Blackbirds (Ictaridae) and starlings (Sturnus vulgaris) will frequently use feedlots, dairies, and agricultural pastures, and thus are likely to encounter human pathogens at those sites (Odermatt et al., 1998; Kaleta, 2002; Nielsen et al., 2004). Both species are also likely to use agricultural crop fields as sources of food and grit, thereby providing an opportunity to contaminate soils and crops with their feces. Starlings may also use crop storage and processing facilities as roost sites, providing additional opportunities to contaminate produce: House sparrows. (Passer domesticus) have a more restricted range. However, this spècies is commonly associated with poultry houses, feedlots, and dairies, and commonly roosts and nests in crop storage and processing facilities 
124 CHAPTER 6: Sapro-Zoonotic Risks Posed by Wild Birds in Agricultural Landscapes

(Craven et al., 2000; Kirk et al., 2002). Other species of passerines are more likely to use only the agricultural fields; thus their risk of contaminating field crops will be based on their exposure to pathogens in the general environment (Boutin et al., 1999; Laiolo, 2005).

\section{BACTERIAL DISEASES}

\section{Campylobacter}

Campylobacter is widespread in wild birds (Luechtefeld et al., 1980). High isolation rates have been obtained in gulls (Larus spp., 15-50\%), crows (Corrus corone cornix, Corvus levaillanti, and Corvus corone, 34-89\%), blue magpies (Cyanopica cyanus, 20\%), gray starlings (Sturnus cineraceus, 14\%), and pigeons (4-26\%) (Ito et al., 1988; Quessy and Messier, 1992; Casanovas et al., 1995). In cases where stomach contents have been analyzed, it is evident that the birds have visited landfills, thus indicating the importance of food habits as a primary factor in the varying prevalence of C. jejuni (Kapperud and Rosef, 1983). Campylobacter spp. are also widely distributed in aquatic environments and in sewage effluents and agricultural runoff, enviroiments conducive to exposing water fowl to the pathogen (Brown et al., 2004). Campylobacter species may survive, and remain potentially pathogenic, for long periods in aquatic environments, but leșs so on terrestrial substrates (Krampitz and Hollander, 1999).

Campylobacters are emerging as one of the most significant causes of human infections worldwide, and the role that terrestrial birds and water fowl have in the spread of disease is beginning to be elucidated. On a world scale campylobacters are possibly the major cause of human gastrointestinal infections. The possible role of wild birds in causing human disease is still uncertain. For example, starlings shed Campylobacter at high rates, suggesting that they may be a source of human and farm-animal infection. However, based on genetic analysis, Colles et al. (2008a) concluded that these bacteria were distinct from poultry or human disease isolates, with the ST-177 and ST-682 clonal complexes possibly representing starlingadapted genotypes. Thus, these authors concluded that there was no evidence that wild starlings represent a major source of Campylobacter infections of food animals or humans. Similarly, Colles et al. (2008b) investigated wild geese as a potential source of Campylobacter infection for humans and farm animals in waterborne disease outbreaks. The authors found that large numbers of wild geese carry Campylobacter; however, there was limited mixing of Campylobacter populations among the different sources examined. Thus, they concluded that genotypes of $C$. jejuni isolated 


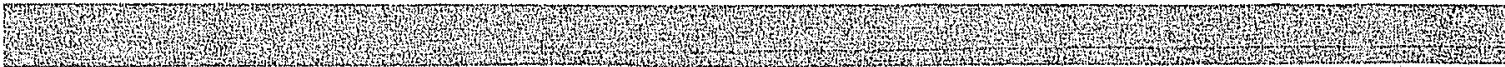

from geese are highly host specific, and geese were unlikely to be the source of the human disease outbrealks. In contrast, French et al. (2008) identified members of Campylobacter clonal complexes ST-45, ST-682, and ST-177 recovered from starling feces as being indistinguishable from those observed in human cases, and concluded that wild birds could contribute to the burden of campylobacteriosis in preschool children at playgrounds.

\section{Chlamydia}

Avian chlamydiosis was originally called "parrot fever.". However, recent studies have shown that parrot fever and ornithosis are the same disease manifested in different species and are all caused by the bacterium Chlamydophila psittaci (Andersen and Vanrompay, 2000). Chlamydial infections have been identified in over 150 species of wild birds (Brand, 1989). Generally, these wild birds are asymptomatic. Bacteria are shed sporadically in nasal secretions and feces. Although the natural host reservoir systems are unlenown, its wide occurrence in wild bird populations and the intermittent - infections of farm stock are consistent with exposure to wild birds. Sporadic shedding was seen in experimentally inoculated great-tailed graclles (Cassidix mexicanus) and cowbirds (Molothrus ater), indicating their potential as host-reservoir systems (Roberts and Grimes, 1978). The most probable risk to farm stock and poultry is when wild birds gain access to feed bins and contaminate the bins with their feces. Infection usually occurs through exposure to contaminated aerosol dusts (Page, 1959). Turkeys can become infected by exposure to starlings, common grackles (Quiscalus quiscula), and brown-headed cowbirds (Roberts and Grimes,1978; Grimes et al., 1979). Serovars D and E can result in 50 to $80 \%$ morbidity and 5 to $30 \%$ mortality in turkeys (Andersen, 1997). In ducks the economic impact is also significant, with morbidity and mortality ranging from 10 to $80 \%$ and 0 to $30 \%$, respectively (Andersen et al., 1997). Infections to mammalian farm stock can also be a cause of health and economic concern (Shewen, 1980). Wild avian strains also can infect mammals, including humans, and can cause severe disease or death (Andersen and Vanrompay, 2000).

\section{Escherichia coli}

The most important reservoir for verocytotoxin-producing Escherichia coli (VTEC) is considered to be ruminants, particularly cattle, though VTEC can be isolated from many mammals and birds (Wallace et al., 1997; Rice et al., 2003). Infection of humans by VTEC may result in combinations of watery diarrhea, bloody diarrhea, and hemolytic uremic syndrome. Severe disease in the form of bloody diarrhea and the hemolytic uremic syndrome is 
126. CHAPTER 6: Sapro-Zoonotic Risks Posed by Wild Birds in Agricultural Landscapes

attributable to Shiga toxin (Stx), which exists as two major types, Stxl and Stx2 (Gyles, 2007). Humans can become infected through contamination of food and water, as well as through direct contact. Given the propensity of certain species of birds to frequent facilities or pastures used by ruminants there remains a distinct possibility that wild birds may play a role in the transmission of VTEC.

Several studies have implicated wild birds in the transmission of VTEC based on the similar characterizations between avian and human isolates (Asalkura et al., 2001; Kobayashi et al., 2002). Numerous studies have documented the presence of Stx-producing E. coli (STEC) in pigeons (Morabito et al., 2001), gulls (Makino et al., 2000), water fowl (Feare et al., 1999; Kullas et al., 2002), and passerines (Nielsen et al., 2004; Kobayashi et al., 2008). Other human virulence factors have also been identified in these species, including eae, cldt, CNF-1, CNF2, K1, LT, hlyA, SLT-I, SLT-II, STa, and STb (Morabito et al., 2001; Kullas et al., 2002; Fulkryama et al., 2003; Pedersen et al., 2006). In addition, phylogenic studies have illustrated the similarity of VTEC based on a number of measures (Malkino et al., 2000). Though less common, a few studies have shown direct linkages and phylogenetic relatedness between avian VTEC and isolates causing human illness (Sonntage et al., 2005; Eiidokun et al., 2006).

Though VTEC are widely reported in the species groups just-discussed;-Canada geese have been implicated as the most likely source of nonpoint source pollution of inland waters. Molecular fingerprints of $E$. coli isolated from regional populations showed an unexpectedly high percentage of isolates identified as having a wildlife origin (geese and deer). Geese were the dominant source of $E$. coli $(44.7-73.7 \%$ of the total sources) in four subwatersheds, followed by cows (10.5-21.1\%), deer (10.5-18.4\%), humans (5.3-12.9\%), and unidentifiable sources (0.0-11.8\%) (Somarelii-et al., 2007).

Public pressure is mounting to reduce or eliminate antimicrobials as ingredients of feed for poultry and other agricultural animals, primarily due to the fear of multidrug-resistant bacteria in clinical infections in both animals and humans. Wild birds have been implicated as reservoirs and as vectors for the spread of antibiotic resistant strains of $E$. coli. Gibbs et al. (2007) found drug resistant strains of $E$. coli in feces of yellow-headed blackbirds (Xanthocephalus xanthocephalus). Doleiska et al. (2008) reported E. coli resistant to 12 antimicrobials in $9 \%(n=54)$ of isolates from house sparrows (Passer domesticus). Greater than $95 \%$ of $E$. coli isolates from Canada geese in agricultural environments were resistant to penicillin $G_{\text {, }}$ ampicillin, cephalothin, erythromycin, lincomycin, sulfathiazole, and vancomycin; no. E. coli were resistant to bacitracin or ciprofloxacin (Fallacaara et al., 2001; Cole et al., 2005; Middleton and Ambrose, 2005). 
Most studies have focused only on the serotype O157:H7/H-; however, there are suggestions that wild birds may be involved in the transmission of other pathogenic serotypes (Kullas et al., 2002). Morabito et al. (2001) described widespread, clonally related isolates of $E$. coli $\mathrm{O} 45, \mathrm{O} 18 \mathrm{ab}$, and 075 serotypes in several pigeon flocks. The overall prevalence was similar between three flocks (10.8\%), with evidence of Stx-producing E. coli (STEC).

\section{Listeria}

Listeriosis in humans is caused by infection by Listezia monocytogenes. All serovars of $L$. monoctyogenes are considered human pathogens, and the most potentially virulent are $4 \mathrm{~b}, 1 / 2 \mathrm{~b}$, and $1 / 2 \mathrm{a}$. L. monocytogenes is commonly associated with soils and feces in the environment and may be one of the most ubiquitous microorganisms in the soil. Human exposure is most likely through ingestion of contaminated food, but hand-oral contact or inhalation may also occur. Approximately 1 to $10 \%$ of the human population is thought to carry $L$. monocytogenes asymptomatically in the intestines. Healthy people rarely become ill after exposure. Serious cases almost always occur in the elderly, pregnant women, newborns, and those who are debilitated or immunocompromised (Acha and Szyfres, 2003).

Listeria spp. are commonly found in birds (Harken et al., 1986; Fenlon, 1985). Overall, the prevalence detected across species lies within the same range. On the lower end Quessy and Messier.(1992) found a prevalence of $9.5 \%$ in fecal samples of ring-billed gulls (Larus delawarensis). Clark and Sullivan (unpublished data) found prevalence ranging from 8 to $12 \%$ from Canada goose (Branta canadensis) fecal samples from five states (Colorado, New York, Pennsylvania, Washington, and Wisconsin) that were collected throughout the year. On the higher end, investigators have found prevalences of $43.2 \%$ in crows and $36 \%$ in gulls (Helstrom et al., 2008). Wild birds may pose a risk to human health. The magnitude of prevalence may be largely die to local environmental conditions that birds may visit, such as landfills, sewage treatment facilities, and livestock facilities. Visitation of such environments may also impact exposure and carriage of virulent strains of Listeria. The serovars $1 / 2 \mathrm{a}$ and $4 \mathrm{~b}$ predominated in the eight serotyped $L$. monocytogenes isolates in the Yoshida et al: $(2,000)$ study. Similar geneotypes have been found in wild birds and local fresh food markets as well (Zhang et al., 2007; Mousupye and von Holy, 2000; Fellstrom et al., 2007).

\section{Salmonella}

- Various Salmonella strains have been isolated from a range of wild-bird species. Given the ubiquitous nature of the host range, and the pathogenicity 
128 CHAPTER 6: Sapro-Zoonotic Risks Posed by Wild Birds in Agricultural Landscapes

of the organism to humans, caution should be exercised anytime there is exposure to fecally contaminated surfaces or soils. When sapro-zoonotic infections do occur, 99\% of the documented cases appear to have resulted from aerosol exposure (Haag-Wackernagel and Moch, 2004).

Gulls appear to pose the greatest risk of infection and carriage. This is perhaps owing to their greater propensity to visit sewage treatment ponds and thus acquire pathogens. Salmonella prevalence in gulls ranges between 1 to 55\% (Butterfield et al., 1983; Fenlon, 1981, 1983; Sixl et al., 1997; Casanova, 1995|. Several genetic and epidemiological studies have linked transport of pathogens from the site of acquisition to distant sites, including food-processing facilities and stoclkyards (Coulson et al., 1983; Nesse et al., 2005). Persistence in marked free-ranging gulls and experimentally infected sparrows was shown to be limited, approximately 10 days (Snoeyenbos et al., 1967; Palmgren et al., 2006). Other genetic studies have shown that strains carried by gulls are similar to human pathogens.

Pigeons are generally characterized by a low prevalence $(3-4 \%)$ of Salmonella (Pasmans et al., 2004; Tanaka et al., 2005; González-Acuña et al., 2007). Despite the low prevalence, studies have implicated pigeons and sparrows in the maintenance of the pathogen at feedlots and dairies (Quevedo et al., 1973; Connolly et al., 2006; Pedersen et al., 2006).

\section{FUNGAL DISEASES}

\section{Aspergillus}

Aspergillus spp. are rapidly growing molds most commonly associated with decaying matter and the feces of water fowl and raptors, although a variety of wild birds and domestic poultry are also known to become infected with Aspergillus spp. (Buxton and Sommer, 1980; Friend, 2006):. In animals, greater than 90\% of infections are causëd by A. fumigatus (Quinin, 1994). The highest prevalence of $A$. fumigatus in water fowl is in winter. The most susceptible people for the respiratory and allergic complications of infection in populations are those who are immunocompromised or are on extended regimens of medication (Latge, 2001).

\section{Cryptococcus}

Cryptococcus neoformans is a fungus typically associated with bird feces (Blaschike-Hellmessen, 2000). C. neoformans typically affects only the immunocompromised. Cryptococcal infection may cause a pneumonia-like illness, with shortness of breath, coughing, and fever. Skin lesions may also occur: Another common form of cryptococcosis is central nervous system 
infection, such as meningoencephalitis. The primary risk for infection is inhaling dusts containing contaminated feces. Pigeons appear to be the primary wild bird involved in transmission to humans, though C. neoformans has been detected in a variety of other species (Pollock, 2003; Cafarchia et al., 2006; Rosario et al., 2008). Prevalence in pigeons may range between 9 and 19\% (Weber and Shafer, 1991; Soogarun et al., 2006). Unlike Histoplasma, C. neoformans viability in the environment is limited. Ruiz et al. (1982) showed that viability of C. neoformans decreased from 86 to $50 \%$ over the course of a year, once pigeons were excluded from a roost. They attributed this decrease in viability to desiccation.

\section{Histoplasma}

Histoplasma capsultatum is a zoonotic fungal pathogen, commonly found in soils and bird feces, that affects the respiratory system (Ajello, 1964). In endemic areas of the United States as much as 80 to $90 \%$ of the human pop-. ulation is-infected (Rubin et al., 1959). Fewer than 10\% of those who inhale airborne spores develop a pulmonary infection. However, the pulmonary form can disseminate and is potentially fatal if not treated. Acute pulmonary histoplasmosis is the most dramatic form of the disease and occurs in people who have inhaled massive doses of spores. Chronic infection in humans can result in permanent lung damage. People with HN are most susceptible to the disseminated form of the illness. People at highest risk are those working in agriculture, particulariy poultry operations, or those people coming in contact with bird feces associated with bird roosts (Dodge et al., 1965; Tosh et al., 1966). Such roosts are lilkely to be associated with dense vegetation (i.e., agricultural wind brealks), trees, or storage or processing sheds. Because transmission is through breathing dust particles containing spores, any disturbance of contaminated soil carn cause infection (Storch et al., 1980; Stoberski et al., 1996). Soil studies have shown that the viable spores persist in contaminated soils over many years (9-13+ years; DiSalvo and Johnson, 1979), long after bird activity at a site has since ceased (Gustafson et al., 1981). Moreover, residents downwind from contaminated disturbed soils can become infected (Latham et al., 1980; Chick et al., 1981). Formalin has been used to sterilize soils contaminated with Histoplasma and deemed to be at high risk of further infection to local human populations (Smith et al., 1964; Tosh et al., 1967; Bartlett et al., 1984). Although Histoplasma has been detected in the feces of many species of birds, pigeons, blackbirds, and starlings are the most likely wild birds to be a source of soil contamination, and the species most likely to be associated with roosts near agriculture production or processing (Schwarz et al., 1957; Pollack, 2003; Cermeno et al., 2006). 


\section{PARASITIC DISEASES}

\section{Cryptosporidia}

Cryptosporidium parvum is an important gastrointestinal parasite of humans and other animals that can be transmitted via contamination of food and water (Mackenzie et al., 1994; Millar et al., 2002). Symptoms may be long-lasting and include diarrhea, loose or watery stool, stomach cramps, upset stomach, and a slight fever (Fayer et al. 1998). Some people have no symptoms. In persons with average immune systems, symptoms usually last about two weeks. Water fowl in general, but Canada geese in particular, have been implicated in the contamination of water (Hatch, 1996; Smith et al., 1993; Graczyk et al., 1997; Fallacara et al., 2004), and oocytes recovered from feces have been demonstrated to be infectious (Graczyk et al., 1998).

\section{Microsporidia}

Microsporidians. (Encephalitozoon intestinalis, E. hellem, E. cuniculi, $E$. bieneusi) are obligate intracellular parasites that are increasingly involved in opportunistic infections of the immunocompromised and immunocompetent people (Weber et al., 1994). E. hellem has been the species most commonly associated with avian hosts (Slodkowicz-Kowalska et al., 2006). Epidemiological evidence strongly supports contaminated water, including water used for crop production, as a significant risk factor for human disease (Dowd et al., 1998; Fournier et al., 2000; Mathis et al., 2005; ThurstonEnriquez et al., 2002); avian contamination of surface water via defecation is an important contributory risk factor for pathogen transmission (Slodkowicz-Kowalska et al., 2006). Although water-borne transmission is the most likely avenue for opportunistic infection of humans, a recent study by Haro et al. (2005) showed that pigeon feces was positive for E. Bieneusi (9.7\% prevalence), $E$. intestinalis ( $4 \%$ prevalence), and $E$. hellem (1\% prevalence), and $4.8 \%$ of pigeons were coinfected. Bart et al. (2008) found similar prevalence. The authors concluded that there was no barrier to transmission from pigeons to humans.

\section{Toxoplasma}

Toxoplasma gondii is a common single-celled parasite responsible for infection of more than 60 million people in the United States each year. Infection can be acquired via hand-to-mouth contact with feces, contaminated soil, water, or raw meat. In most cases, the hosts' natural immune system clears the disease, and most healthy humans are rarely aware that 


\begin{tabular}{|c|c|c|c|}
\hline Order & $\begin{array}{l}\text { Common } \\
\text { Group Name }\end{array}$ & $\begin{array}{l}\text { Prevalence } \\
\text { Range (\%) }\end{array}$ & Reference \\
\hline Charadriiformes & Gulls & $6-16$ & $\begin{array}{l}\text { Literak et al., 1992; Burridge } \\
\text { et al., } 1979\end{array}$ \\
\hline Anseriformes & Ducks, geese & $1-28$ & Literak et al., 1992; Pak, 1976 \\
\hline Galliformes & $\begin{array}{l}\text { Pheasants, quail, } \\
\text { turkey }\end{array}$ & $2-19$ & Literak et al., 1992 \\
\hline Columbiformes & Pigeons, doves & $5-12$ & $\begin{array}{l}\text { Literak et al., 1992; Gibson and } \\
\text { Eyles, 1957; Jacobs et al., } \\
\text { 1952; Catar, } 1974\end{array}$ \\
\hline \multirow[t]{3}{*}{ Passeriformes } & $\begin{array}{l}\text { House sparrow } \\
\text { (Passer } \\
\text { domesticus) }\end{array}$ & $1-18$ & $\begin{array}{l}\text { Hejlicek et al., 1981; Ruiz and } \\
\text { Frenkel, 1980; Literak et al., } \\
\text { 1992; Pak, } 1976\end{array}$ \\
\hline & $\begin{array}{l}\text { Starling (Sturnus } \\
\text { vulgaris) }\end{array}$ & 1 & Literak et al., 1992; Pak 1976 \\
\hline & $\begin{array}{l}\text { Crow (Corvus } \\
\text { brachyrhynchos) }\end{array}$ & 1 & Finlay and Manwell, 1956 \\
\hline
\end{tabular}

they are infected. Symptoms include flu-like symptoms and swollen joints and fatigue. However, people with impaired immune systems, embryos, and neonates are particularly vulnerable to severe consequences of infection (e.g., eye and brain damage). Birds are included in the extensive list of wildlife species implicated as carriers of this parasite (Coutelen et al., 1953; Drobeck et al., 1953; Siim et al., 1963; Dubey, 2002). The prevalence of $T$. gondii in wild birds likely to be associated with agricultural landscapes is moderately high (Table 6.1). This is of some concern because T. gondii is readily transmitted through the fecal-water route arid represents a risk for contaminating crops or water sources used by humans for consumption or food processing (Bahiia-Oliveira et al., 2003). Finally, Human populations can be affected by exposure to feces associated with roosts (Peach et al., 1989).

\section{MITIGATION OPTIONS}

Several excellent reviews exist on the general practices of excluding and repelling birds from agricultural landscapes (Hyngstom et al., 1994; Mason, 1995; Conover, 2002; Linz, 2003). Other venues for research and methods for animal damage control can be found in the Proceedings of the Vertebrate Pest Conference, Proceedings of Animal Damage Management Conference, and the journals of human-wildlife conflict: Tournal of Wildlife Management, Wildlife Society Bulletin, and Wildlife Research. 
Lethal control is not generally an option for bird control, owing to federal and state statues and prohibitions. Nonlethal methods to scare birds off fields are the only recourses available to growers. However, in reality, it is not practical to exclude all wild birds from large agro-ecosystems. It is feasible using integrated pest management approaches to limit populations in specific fields (Avery, 1989; Mason and Clark, 1992, 1996; Clark, 1998). Methods can include the use of frightening devices, such as visual deterrents, pyrotechniques, propane exploders, or alarm calls, but it is important to avoid presenting cues on a systematic or regular basis so as to avoid habituation. A review of each of these methods and their successes and failures can be found in the handbook The Prevention and Control of Wildlife Damage (Hyngstrom et al., 1994). The difficulty with the approaches outlined in the handbook is one of expense and human vigilance, both of which are at the root cause of failure. Stevens et al. (2000) explored the use of demand performance systems employing radar technologies to activate a variety of bird scaring devices. The method was successful at keeping migratory birds off hazardous waste ponds of 180 and 90 acres for over a year. The principal drawback of the system was expense. Most agricultural operations could not afford such protection.

Chemical repellents have been tried, but not all crops are amenable to their use owing to expense and regulatory restrictions (Clark, 1997). Nonetheless, several products have been developed, for example methy]. anthranilate and anthraquinone-based products, and several other investigatory repellents have been evaluated (Avery and Mason, 1997; Cummings et al., 2002; Avery et al., 2005; Werner et al., 2008).

\section{SUMMARY}

Wild birds are capable of pathogen carriage, acting as reservoirs, and becoming infected with a wide variety of pathogens, some of which are zoonoses." This review did not attempt to provide an exhaustive list. Rather its intent was to focus on the avian species and pathogens that represented the greatest.likelihood to be of concern at the agricultural production and processing levels. Unfortunately, little direct evidence bears on this issue; hence, risk was assessed using information derived from urban human health, water quality, poultry, livestock production, wildlife health, and the veterinary literature. Despite the lack of direct evidence relating to birds and the risks to farm-side production and processing of produce, it appears there is ample evidence to support the notion that birds can pose a human health risk by serving as a source of contamination of produce and crops. Nonetheless, more detailed empirical and risk-modeling studies are needed. Moreover, 
such studies should be integrated into a larger ecological perspective of the values of birds to agroecosystems balanced against the health risks they pose. Finally, studies and analyses also should incorporate assessments of mitigation management strategies in the context of economic, ecological, and public-health valuations. These approaches are clearly beyond the scope of this review, but should be seriously considered over a simplistic interpretation of disease risk posed by wild birds and measures needed to eliminate them from agro-ecosystems.

\section{REFERENCES}

Acha, P. N. and Szyfres, B. (2003). Zoonoses and communicable diseases common to man and animals. Volume 1. Bacterioses and mycoses: 3rd ed. Listeriosis, pp. 168-179. Washington, DC: Pan American Health Organization; Scientific and Technical Publication No. 580.

Ajello, L. (1964). Relationship of histoplasma capsulatum to avian habitats. Public Health Rep. 79, 266-270.

Amano, T., Ushiyama; K., Fujita, G., and Higuchi, H. (2007). Predicting grazing damage by white-fronted geese under different regimes of agricultural management and the physiological consequences for the geese. Joumal of Applied Ecology 44, 506-515.

Andersen, A. A. (1997). Two new serovars of Chlamydia psittaci from North American birds. J. Vet. Diagn. Invest. 9, 159-164.

Andersen, A. A. and Vanrompay, D. (2000). Avian chlamydiosis. Rev. Sci. Tech. 19, 396-404.

Anonymous. (2002). Compendium of measures to control Chlamydophila psittaci (formerly Clamydia psittaci) infection among humans (Psittacosis and pet birds) In www.avma.org/pubhlth/psittacosis.asp, Vol. 2003. National Association of State Public Health Veterinarians.

Asaliura, H:, Makino; S., Kobori, H. et al. (2001). Pliylogenetic diversity and similarity of active sites of Shiga toxin (stx) in Shiga toxin-producing Escherichia coli (STEC) isolates from humans and animals. Epidemiol Infect. 127; 27-36.

Avery, M. L. (1989). Experimental evaluation of partial repellent treatment for reducing bird damage to crops. Journal of Applied Ecology 26, 433-439.

Avery, M. L. and Mason, J. R. (1997). Feeding responses of red-winged blackbirds to multisensory repellents. Crop Protection 16, 159-164.

Avery, M. L., Werner, S. J., Cummings, J. L. et al. (2005). Caffeine for reducing bird damage to newly seeded rice. Crop Protection 24, 651-657.

Bahia-Oliveira, L. M. G., Jones, J. L. Azevedo-Silva, T. et al. (2003). Highly endemic, waterborne toxoplasmosis in North Rio de Janeiro State, Brazil. Emerging Infectious Diseases 9, 55-62.

Bart, A., Wentink-Bonnema, M., Feddema, E. R. et al. (2008). Frequent occurrence of human-associated microsporidia in fecal droppings of urban pigeons in Amsterdam, The Netherlands. Appl. Environ. Microbiol. 74, 7056-7058. 
134 CHAPTER 6: Sapro-Zoonotic Risks Posed by Wild Birds in Agricultural Landscapes

Bartlett, P. C., Weeks, R. T., and Ajello, I. (1982). Decontamination of a Histoplasma capsulatum-infested bird roost in Illinois. Arch. Environ. Health 37, 221-223.

Beuchat, I. R. and Ryu, J. H. (1997). Produce handling and processing practices. Emerg. Infect. Dis. 3, 459-465.

Blaschire-Hellinessen, R. (2000). Cryptococcus species-Etiological agents of zoonoses or sapronosis? (in German) Mycoses 43 Suppl 1, 48-60.

Brand, C. J. (1989). Chlamydial infections in free-living birds. J. Am. Vet. Med. Assoc. 195, 1531-1535.

Brown, P. E., Christensen, O. F., Clough, H. E. et al. (2004). Frequency and spatial distribution of environmental Campylobacter spp. Appl. Environ. Microbiol. 70, 6501-6511.

Boutin, C., Freemark, K. E., and Kirk, D. A. (1999). Farmland birds in southem Ontario: Field use, activity patterns, and vulnerability to pesticide use. Agriculture, Ecosystems and Environment 72, 239-254.

Burridge, M. J., Bigler, W. T., Forrester, D. T., and Hennemann, J. M. (1979). Serologic survey for Toxoplasma gondii in wild animals in Florida. J. Am. Vet. Med. Assoc. 175, 964-967.

Butterfield, I., Coulson, J. C., Kearsey, S. V. et al.'(1983). The herring gull Lanus argentatus as a carrier of Salmonella. T. Hyg. (Lond). 91, 429-436.

Buxton, I. and Sommer, C. V. (1980). Serodiagnosis of Aspergilltus fumigatus antibody in migratory ducks. Avion Dis. 24, 446-454.

Cafarchia, C., Romito, D., Iatta, R. et al. (2006). Role of birds of prey as carriers and spreaders of Ciyptococcus neoformans and other zoonotic yeasts--Med.-Mycol. $44,485-492$.

Casanovas, L., de Simón, M., Ferrer, M. D. et al. (1995). Intestinal carriage of campylobacters, saimonellas, yersinias and listerias in pigeons in the city of Barcelona. T. Appl. Bacteriol. 78, 11-13.

Catar, G. (1974). Toxoplazmoza v elkologickych podmienkach na Slovenslku (in Slovalcian). Biologicke Prace (Bratislava) 20, 1-38.

Cermeno, T. R., Hernandez, I., Cabello, I. et al. (2006). Cryptococcus neoformans and Histoplasma capsulatum in dove's (Columba livia) excreta in Bolivar state, Venezuela. Rev. Latinoam. Microbiol. 48, 6-9.

Chick, E. W., Compton, S. B., Pass, T., III et al. (1981). Hitchcock's birds, or the increased rate of exposure to histoplasma from blackbird roost sites. Chest 80, 434-438.

Clarenburg, A. and Dornickx, C. G. T. (1933). Nahnungmittelvergiftung bei Menschen in Zusammendgang mit Tauben paratyphose. Zscher. Hyg. Inf. Krankh. 114, 31-41.

Clark, L. (1997). A review of the bird repellent effects of 117 carbocyclic compounds. In Repellents in wildlife management (T. R. Mason, Ed.), pp. 343-352 (August 8-10, 1995, Denver, CO). Colorado State University, Fort Collins, CO.

Clark, L. (1998). Review of bird repellents. In Eighteenth Vertebrate Pest Conference (Barker, R. O. and Crabb, A. C., Eds.), pp. 330-337 (March 2-5, 1998, Costa Mesa, CA). 
Cole, D., Drum, D. J., Stalknecht, D. E. et al. (2005). Free-living Canada geese and antimicrobial resistance. Emerg. Infect. Dis. 11, 935-938.

Colles, F. M., Dingle, K. E., Cody, A. T., and Maiden, M. C. (2008a). Comparison of Campylobacter populations in wild geese with those in starlings and free-range poultry on the same farm. Appl. Environ. Microbiol. J74, 3583-3590.

Colles, F. M., McCarthy, N. D., Howe, J. C. et al. (2008b). Dynamics of Campylobacter colonization of a natural host, Sturnus vulgaris (European Starling). Environ. Microbiol. S29. [Epub ahead of print; www.wiley.com/bw/journal.asp? ref $=1462-2912]$

Conn, D. B., Weaver, J., Tamang, L., and Graczyk, T. K. (2007). Synanthropic flies as vectors of Cryptosporidium and Giardia among livestock and wildlife in a multispecies" agricultural complex. Vector-Borne and Zoonotic Diseases 7, 643-651.

Connolly, J. H., Alley, M. R., Dutton, G. J., and Rogers, L. E. (2006). Infectivity and persistence of an outbreak strain of Salmonella enterica serotype Typhimurium DT160 for house sparrows (Passer domesticus) in New Zealand. N. Z. Vet. T. $54,329-332$.

Conover, M. R. (2002). Resolving human-wildlife conflicts: The science of wildlife damage management. CRC Press, New York.

Coulson, J. C., Butterfield, J., and Thomas, C. (1983). The herring gull Larus argentatus as a likeiy transmitting agent of Salmonella montevideo to sheep and cattle. T. Hyg. (Lond). 91, 437-443.

Coutelen, F., Biguet, J., Doby, J. M., and Deblock, S. (1953). Le probleme de toxoplamoses aviares. Receptivite variable de vuelques oiseaux a une souche humaine de toxoplasmes. Ann. Parasitol. Hum. Comp. 28, 129-156.

Craven, S. E., Stern, N. J., Line, E. et al. (2000). Determination of the incidence of Salmonella spp., Campylobacter jejuni, and Clostridium perfingens in wild birds near broiler chicken houses by sampling intestinal droppings. Avian Dis. 44, 715-720.

Cummings, J. L., Avery, M. L., Mathre, O. et al. (2002). Field evaluation of Flight Control to reduce blackbird damage to newly planted rice. Wildlife Society Bulletin 30(3), 81:6-820.

Davies, J. W., Anderson, R. C., Karstad, L., and Trainer, D. O. (1971). Infectious and parasitic diseases of wild birds. Iowa State University Press, Ames, IA.

Disalvo, A. F. and Johnson, W. M. (1979). Histoplasmosis in South Carolina: Support for the microfocus concept. Am. T. Epidemiol. 109, 480-492.

Dodge, H. T., Ajello, L., and Engelke, O. K. (1965). The association of a bird-roosting site with infection of school children by Histoplasma capsulatum. Am. T. Public. Health Nations Health 55, 1203-1211.

Dolejská, M., Senk, D., Cízelc, A. et al. (2008). Antimicrobial resistant Escherichia coli isolates in cattle and house sparrows on two Czech dairy farms. Res. Vet. Sci. 85, 491-494.

Dowd, S. E., Gerba, C.P, and Pepper, I. L. (1998). Confirmation of the human pathogenic microsporidia Enterocytozoon bieneusi, Encehphalitozoon intestinalis, and Vittaforma comeae in water. Appl. Environ. Microbiol. 64, 3332-3335.

Drobeck, H. P., Manwell, R. D., Bernstein, E., and Dillon, R. D. (1953). Further studies of toxoplasmosis in birds. Am. J. Hyyg. 58, 329-339. 
Dubey, T. P. (2002). A review of toxoplasmosis in wild birds. Vet. Parasitol. 106, 121-153.

Ejidokun, O. O., Walsh, A., Barnett, T. et al. (2006). Human Vero cytotoxigenic Escherichia coli (VTEC) 0157 infection linked to birds. Epidemiol. Infect. 134, 421-423.

Feare, C. T., Sanders, M. F., Blasco, R., and Bishop, J. D. (1999). Canada goose (Branta canadensis) droppings as a potential source of pathogenic bacteria. T. R. Soc. Health 119, 146-155.

Fallacara, D. M., Monahan, C. M., Morishita, T. Y., and Wack, R. F. (2001). Fecal shedding and antimicrobial susceptibility of selected bacterial pathogens and a survey of intestinal parasites in free-living waterfowl. Avian Dis. 45, 128-135.

Fallacara, D. M., Monahan, C. M., Morishita, T. Y. et al. (2004). Survey of parasites and bacterial pathogens from free-living waterfowl in zoological settings. Avian Dis. 48, 759-767.

Fayer, R., Graczyk, T.K, Lewis, E. J. et al. (1998). Survival of infectious Cryptosporidium parvum oocysts in seawater and Easter oysters (Crassostrea viginica) in the Chesapeake Bay. Appl. Environ. Microbiol. 64, 1070-1074.

Fenlon, D. R. (1981). Seagulls (Larus spp.) as vectors of salmonellae: An investigation into the range of serotypes and numbers of salmonellae in gull faeces. T. Hyg. (Lond). 86, 195-202.

Fenlon, D. R. 11983). A comparison of Salmonella serotypes found in the faeces of gulls feeding at a sewage works with serotypes present in the sewage. T. Hyg. (Lond). 91, 47-52.

Fenlon, D. R. (1985). Wild birds and silage as reservoirs of Listeria in the agricultural. environment. J Appl Bacteriol. 59, 537-543.

Fournier, S., Liguory, O., Santillana-Hayat, M., et al. (2000). Detection of microsporidia in surface water: A one-year follow-up study. FEMS Immunol. Med. Microbiol. 29, 95-100.

French, N. P., Midwinter, A., Holland, B. et al. (2008). Molecular epidemiology of Campylobacter jejuni isolated from wild bird faecal material in children's playgrounds. Appl. Environ. Microbiol. [Epub ahead of print; http://aem.asm.org/]

Fricker, C. R. (1984). A note on Salmonella excretion in the black headed gull (Larus ribibundus) feeding at sewage treatment works. J. Appl. Bacteriol. 56, 499-502.

Friend, M. (2006). Disease emergence and resurgence: The wildlife-human connection. Circular 1285. US Department of Interior and US Geological Survey, Reston, VA.

Fukuyama, M., Funuhata, K., Oonalka, K. et al. (2003). Isolation and serotypes of Vero toxin-producing Escherichia coli (VTEC) from pigeons and crows Kansenshogaku Zasshi. 77, 5-9.

Gibbs, P. S., Kasa, R., Newbrey, J. L. et al. (2007). Identification, antimicrobial resistance profiles, and virulence of members from the family Enterobacteriaceae from the feces of yellow-headed blackbirds (Xanthocephalus xanthocephalus) in North Dakota. Avian Dis. 51, 649-655.

Giloson, C. L. and Eyles, D. E. (1957). Toxoplasma infections in animals associated with a case of human congenital toxoplasmosis. Am T. Trop. Med. Hyg. 6, 990-1000. 
González-Acuña, D., Silva, G. F., Moreno, S. L. et al. (2007). Detection of some zoonotic agents in the domestic pigeon (Columba livia) in the city of Chillán, Chile. Rev Chilena Infectol. 24, 199-203.

Graczyl, T. K., Cranfield, M. R., and Fayer, R. (1997). Infectivity of Cryptosporidium parvum oocysts is retained upon intestinal passage through a migratory waterfowl species (Canada goose, Branta canadensis). Trop. Med. Int. Health 2, 341-347.

Graczyk, T. K., Fayer, R., Trout, J. M. et al. (1998). Giardia sp. cysts and infectious Cryptosporidium parvum oocysts in the feces of migratory Canada geese (Brant canadensis|. Appl. Environ. Microbiol. 64, 2736-2738.

Graczyk, T. K., Majewska, A. C., and Schwab, K. J. (2008). The role of birds in dissemination of human waterborne enteropathogens. Trends in Parasitology $24,55-59$.

Grimes, J. E., Owens, K. J., and Singer, J. R. (1979). Experimental transmission of Chlamydia psittaci to turkeys from wild birds. Avian Dis. 23, 915-926.

Gustafson, T. L. Kaufman, L., Weelss, R. et al. (1981). Outbrealk of acute pulmonary hisotplasmosis in members of a wagon train. Am. T. Mèd. 71, 759-765.

Gyles, C. L. (2007). Shiga toxin-producing Escherichia coli: An overview. T. Anim. Sci. 85 (13 Suppl), E45-E62.

Haag-Wackemagel, D. and Moch, H. (2004). Health hazards posed by feral pigeons. J Infect. May 48(4), 307-313.

Harkin, J. M. and Phillips, W. E., Ir. (1986). Isolation of Listeria monocytogenes from an eastern wild turkey. J. Wildl. Dis. 22, 110-112.

Haro, M., Izquierdo, F., Henriques-Gil, N. et al. (2005). First detection and genotyping of human-associated nicrosporidia in pigeons from urban parks. Appl. Environ. Microbiol. 71, 3153-3137.

Hatch, J. J. (1996). Threats to public health from gulls (Laridae). Int. J. Environ. Health Res. 6, 5-16.

Hejlicek, K., Prosek, F., and Treml, F. (1981). Isolation of Toxoplasma gondii in free-living small maminals and birds. Acta Vet. Brno. 50, 233-236.

Hellström, S., Kiviniemi, K., Autio, T., and Korkeala, H. (2008). Listeria monocytogenes is common in wild birds in Helsinli region and genotypes are frequently similar with those found along the food chain. I Appl Microbiol. Mar 104|3|, 883-888.

Hubálek, Z. (2004). An annotated checklist of pathogenic microorganisms associated with migratory birds. J. Wildl Dis. 40, 639-659.

Hyngstrom, S. E., Timm, R. M., and Larson, G. E. (1994). Prevention and control of wildlife damage. University of Nebraska Cooperative Extension. US Department of Agriculture-Animal and Plant Health Inspection Service-Animal Damage Control. Great Plains Agricultural Council-Wildlife Committee, Lincoln NE.

Ito, K., Kubolkura, Y., Kaneko, K. et al. (1988). Occurrence of Campylobacter jejuni in free-living wild birds from Japan. I. Wildl. Dis. 24, 467-470.

Jacobs, L. Melton, M. L., and Jones, F. E. (1952). The prevalence of toxoplasmosis in pigeons. Exp. Parasitol. 2, 403-416.

Johnston, R. R. and Janiga, M. (1995). Feral pigeons. Oxford Univ. Press, Oxford. 
ISaleta, E. F. (2002). Foot-and-mouth disease: Susceptibility of domestic poultry and free-living birds to infection and to disease-A review of the historical and current literature concerning the role of birds in spread of foot-and-mouth disease viruses. Deutsche Tierarztliche Wochenschrift 109, 391-399.

Kapperud, G. and Rosef, O. (1983). Avian wildlife reservoir of Campylobacter fetus subsp. jejuni, Yersinia spp., and Salmonella spp. in Norway. Appl Environ Microbiol. 45, 375-380.

Tinzelman, I., McLellan, S. L., Amick, A. et al. (2008). Identification of human enteric pathogens in gull feces at Southwestern Lake Michigan bathing beaches. Can. J. Microbiol. 54, 1006-1015.

Kirk, T. H., Holmberg, C. A., and Jeffrey, T. S. (2002). Prevalence of Salmonella spp. in selected birds captured on California dairies. I. Am. Vet. Med. Assoc. 220, 359-362.

Kobayashi, H., Pohjanvirta, T., and Pellkonen, S. (2002). Prevalence and characteristics of intimin- and Shiga toxin-producing Escherichia coli from gulls, pigeons and broilers in Finland. I Vet. Med. Sci. 64, 1071-1073.

Kobayashi, H., Kanazalki, M., Hata, E., and Kubo, M. (2008). Prevalence and characteristics of eae- and stx-Positive Escherichia coli from wild birds in the immediate environment of Tokyo Bay. Appl. Environ. Microbiol. [Epub ahead of print; http://aem.asm.org]

Krampitz, E. S. and Holländer, R. (1999). Longevity of pathogenic bacteria especially Salmonella in cistern water. Zentralbl. Hyg. Umweltmed. 202, 389-337.

Kruse, H.; Kirkemo, A. M., and Handeland, K. (2004). Wildlife as source of zoonotic infections. Emerg. Infect. Dis. 10, 2067-2072.

Kullas, H., Coles, M., Rhyan, T., and Clark, L. (2002). Prevalence of Escherichia coli. serogroups and human virulence factors in faeces of urban Canada geese (Branta canadensis). Int. J. Environ. Health. Res. 12, 153-162.

Laiolo, P. (2005). Spatial and seasonal patterns of bird communities in Italian agroecosystems. Conservation Biology 19, 1547-1556.

Latgé, J. P. (2001). The pathobiology of Aspergillus fumigatus. Trends Microbiol. 9, 382-389.

Latham, R. H., Kaiser, A. B., Dupont, W. D., and Dan B. B. (1980). Chronic pulmonary histoplasmosis following the excavation of a bird roost. Am. J. Med. 68, 504-508.

Luechtefeld, N. A., Blaser, M. T., Reller, L. B., and Wang, W. L. (1980). Isolation of Campylobacter fetus subsp. jejuni from migratory waterfowl. J. Clin. Microbiol. 12, 406-408.

Linz, G. M., Ed. (2003). Management of North American blackbirds. National Wildlife Research Center, Fort Collins, CO.

Literák, I., Vanlko, R., Dolejská, M. et al. (2007). Antibiotic resistant Eschezichio coli and Salmonella in Russian rooks (Corvus frugilegus) wintering in the Czech Republic. Lett. Appl. Microbiol. 45, 616-621.

Mackenzie, W. R., Hoxie, N. T., Proctor, M. E. et al. (1944). A massive outbreak in Milwaukee of Cyyptosporidium infection transmitted through the public water supply. New England Journal of Medicine 331, 161-167. 
Makino, S., Kobori, H., Asakura, H. et al. (2000). Detection and characterization of Shiga toxin-producing Escherichia coli from seagulls. Epidemiol. Infect. 125, $55-61$.

Mason, J. R., Ed. (1997). Repellents in wildlife management: Proceedings of a symposium. Proceedings of the Second DWRC Special Symposium (August 8-10, 1995, Denver, CO|. National Wildlife Research Center, Fort Collins CO.

Mason, J. R. and Clark, L. (1992). Nonlethal repellents: The development of costeffective, practical solutions to agricuitural and industrial problems. Proceedings Vertebrate Pest Conference 15, 115-129.

Mason, J. R. and Clark, L. (1996). Grazing repellency of methyl anthranilate to snow geese is enhanced by a visual cue. Crop Protection 15, 97-100.

Mathis, A., Weber, B., and Deplazes, P. (2005). Zoonotic potential of the microsporidia. Clin. Microbiol. Rev. 18, 423-445.

McDiarmid, A. (1969). Diseases in free-living wild animals. Academic Press, London, UK.

McKay, H., Watola, G. V., Langton, S. D., and Langton, S. A. (2006). The use of agricultural fields by re-established greylag geese (Anser anser) in England: A risk assessment. Crop Protection 25, 996-1003.

Middleton, J. H. and Ambrose A. (2005). Enumeration and antibiotic resistance -patternis of fecal indicator organisms isolated from migratory Canada geese (Branta canadensis). J. Wildl. Dis. 41, 334-341.

Millar, B. C., Finn, M., Xiao, L. et al. (2002). Cryptosporidium in food-stuffsAn emerging aetiological route of human foodborne illness. Trends in Food Science $\Theta$ Technology 13, 168-187.

Morabito, S., Dell'Omo, G., Agrimi, U. et al. (2001). Detection and characterization of Shiga toxin-producing Escherichia coli in feral pigeons. Vet. Microbiol. 82, 275-283.

Mosupye, F. M. and von Holy, A. (2000). Microbiological hazard identification and exposure assessment of street food vending in Johannesburg, South Africa. Int J Food Microbiol. 61(2-3), 137-145.

Nelson, M., Jones, S. H., Edwards, C., and Ellis, J. C. (2008). Characterization of Escherichia coli populations from gulls, - landfill trash, and wastewater using ribotyping. Dis. Aquat. Organ. 81, 53-63.

Nesse, L. L., Refsum, T., Heir, E. et al. (2005). Molecular epidemiology of Salmonella spp. isolates from gulls, fish-meal factories, feed factories, animals and humans in Norway based on pulsed-field gel electrophoresis. Epiderniol. Infect. $133,53-58$.

Nielsen, E. M., Skov, M. N., Madsen, J. J. et al. (2004). Verocytotoxin-producing Escherichia coli in wild birds and rodents in close proximity to farms. Appl. Environ. Microbiol. 70, 6944-6947.

O'Connor, K. (1992). The herning gull. Dillon Press, Toronto, Canada.

Odermatt, P., Gautsch, S., Rechsteiner, D. et al. (1998). Swarms of starlings in Basel: A natural phenomenon, a nuisance or a health risk? Gesundheitswesen $60,749-754$. 
Pak, S. M. (1976). Toxoplasmosis of birds in Kazalzhstan (in Russian). Contributions Nat. Nidality Dis. 5, 116-125.

Palmgren, H., Aspán, A., Broman, T. et al. (2006). Salmonella in Black-headed gulls (Larus ridibundus); prevalence, genotypes and influence on Salmonella epidemiology. Epidemiol. Infect. 134, 635-644.

Pasmans, F., Van Immerseel, F., Hermans, K. et al. (2004). Assessment of virulence of pigeon isolates of Salmonella enterica subsp. enterica serovar typhimurium variant copenhagen for humans. I. Clin. Microbiol. 42, 2000-2002.

Pedersen, K., Clark, L., Andelt, W. F., and Salman, M. D. (2006). Prevalence of Shiga toxin-producing Escherichia coli and Salmonella enterica in rock pigeons captured in Fort Collins, CO. T. Wildl. Dis. 42, 46-55.

Pollock, C. (2003). Fungal diseases of columbiformes and anseriformes. Vet. Clin. North Am. Exot. Anim. Pract. 6, 351-361.

Quessy, S. and Messier, S. (1992). Prevalence of Salmonella spp., Campylobacter spp. and Iisteria spp. in ring-billed gulls (Larus delawarensis). I Wildl Dis. 28 , 526-531.

Quevedo, F., Lord, R. D., Dobosch, D. et al. (1973). Isolation of Salmonella from sparrows captured in horse corrals. Am. I. Trop. Med. Hyg. 22, 672-674.

Quinn, P. J. (1994). Clinical veterinary microbiology. Elsevier Health Sciences, New York.

Rice, D. H., Sheng, H. Q., Wynia, S. A., Hovde, C. J. (2003). Rectoanal mucosal swab culture is more sensitive than fecal culture and distinguishes Escherichia coli O157:H7-colonized cattle and those transiently shedding the same organism. T. Clin. Microbiol. 41, 4924-4929.

Roberts, I. P. and Grimes, J. E. (1978). Chlamydia shedding by four species of wild birds. Avian Dis. 22, 698-706.

Rosario, I., Acosta, B., and Colom, M. F. (2008). Pigeons and other birds as a reservoir for Cryptococcus spp. Rev. Iberoam. Micol. 25, S1.3-S18.

Rubin, H., Furcolow, M. L., Yates, T. L., and Brasher, C. A. (1959). The course and prognosis of histoplasmosis. Amer. T. Med. 27, 278-288.

Ruiz, A., Neilson, J. B., and Bulmer, G. S. (1982). A one year study on the viability of Cryptococcus neoformans in nature. Mycopathologia 77, 117-122.

Schwarz, J., Baum, G. L., Wang, C. J. et al. (1957). Successful infection of pigeons and chicliens with Histoplasma capsulatimi. Mycopathol. Mycol. Appl. S8, 189-193.

Siim, J. C., Biering-Sorensen, U., and Moller, T. (1963). Toxoplasmosis in domestic animals. Adv. Vet. Sci. 8, 335-429.

Sixl, W., Karpísková, R., and Hubálek, Z. et al. (1997). Campylobacter spp. and Salmonella spp. in black-headed gulls (Larus ridibundus). Cent. Eur. T. Public Health 5, 24-26.

Slodkowciz-Kowalska, A., Graczylk, T. K., Tamang, L. et al. (2006). Microsporidian species lnown to infect humans are present in aquatic birds: Implications for transmission via water? Appl. Environ. Microbiol. 72, 4540-4544.

Smith, C. D., Furcolow, M. L., and Tosh, F. E. (1964). Attempts to eliminate Histoplasma capsulatum from soil. Am. T. Hyg. 79, 170-180. 
Smith, H. V., Brown, J., Soulson, J. C. et al. (1993). Occurrence of oocysts of Cryptosporidium sp. in Larus spp. gulls. Epidemiol. Infect. 110, 135-143.

Snoeyenbos,. G. H., Morin, E. W., and Wetherbee, D. K. (1967). Naturally occurring Salmonella in "blackbirds" and gulls. Avian Dis. 11, 642-646.

Sonntag, A. K., Zenner, E., Karch, H., and Bielaszewslia, M. (2005). Pigeons as a possible reservoir of Shiga toxin 2f-producing Escherichia coli pathogenic to humans. Berl. Munch Tierarztl. Wochenschr. 118, 464-470.

Somarelli, T. A., Makarewicz, J. C., Sia, R., and Simon, R. (2007). Wildlife identified as major source of Escherichia coli in agriculturally dominated watersheds by BOX AlR-derived genetic fingerprints. J. Environ. Manage. 82, 60-65.

Soogarun, S., Wiwanitkit, V., Palasuwan, A. et al. (2006). Detection of Cryptococcus neoformans in bird excreta. Southeast Asian 7. Trop. Med. Public Health 37, 768-770.

Stevens, G. R., Rogue, J., Weber, R., and Clark, L. (2000). Evaluation of a radaractivated, demand-performance bird hazing system. International Biodeterioration \& Biodegradation 45, 129-137.

Stobierski, M. G., Hospedales, C. T., Hall, W. N. et al. (1996). Outbrealk of histoplasmosis among employees in a paper factory-Michigan, 1993. J. Clin. Microbiol. $34,1220-1223$.

Storch, G., Burford, J. G., George, R. B. et al. (1980). Acute histoplasmosis. Description of an outbreak in northern Louisiana. Chest 77, 38-42.

Tanaka, C., Miyazawa, T., Watarai, M., and Ishiguro, N. (2005): Bacteriological survey of feces from feral pigeons in Japan. J. Vet. Med. Sci. 67, 951-953.

Taylor, L. H., Latham, S. M., and Woolhouse, M. E. (2001). Risk factors for human disease emeregence. Philos. Trans. R. Soc. Lond. B. Biol. Sci. 356, 983-989.

Thurston-Enriquez, J. A., Watt, P., Dowd, S. E. et al. (2002). Detection of protozoan parasites and microsporidia in irrigation waters used for crop production. J. Food Prot. 65, 378-382.

Tosh, F. E., Weeks, R. J., Pfeiffer, F. R. et al. (1967). The use of formalin to liell Histoplasma capsulatum at an epidemic site. Am. J. Epidemiol. 85, 259-265.

Tsiodras, S., Kelesidis, T., Kelesidis, I. et al. (2008). Human infections associated with wild birds. J. Infect. 56, 83-98.

Wallace, T. S., Cheasty, T., and Jones, K. (1997). Isolation of vero cytotoxin-producing Escherichia coli O157 from wild birds. J. Appl. Microbiol. 82, 399-404.

Weber, A. and Schäfer, R. (1991). The occurrence of Cryptococcus neoformans in fecal samples from birds kept in human living areas. Berl. Munch. Tierarztl. Wochenschr. 104, 419-421.

Weber, R., Bryan, R. T., Scliwartz; D. A., and Owen, R. L. (1994). Human microsporidial infections. Clin. Microbiol. Rev. 7, 426-461.

Werner, S. T., Cummings, J. L., Tupper, S. K. et al. (2008). Blackbird repellency of selected registered pesticides. Joumal of Wildlife Management 72, 1007-1011.

Wither, A., Rehfisch, M., and Austin, G. (2005). The impact of bird populations on the microbiological quality of bathing waters. Water Sci. Technol. 51, $199-207$. 
142 CHAPTER 6: Sapro-Zoonotic Risles Posed by Wild Birds in Agricultural Landscapes

Yorio, P. and Caille, G. (2004). Fish waste as an alternative resource for gulls along the Patagonian coast: Availability, use, and potential consequences. Mar. Pollut: Bull. 48, 778-783.

Yoshida, T., Sugimoto, T., Sato, M., and Hirai, K. (2000). Incidence of Listeria monocytogenes in wild animals in Japan. J. Vet. Med. Sci. 62, 673-675.

Zhang, Y., Yeh, E., Hall, G. et al. (2007). Characterization of Listeria monocytogenes. isolated from retail foods. Int. I. Food Microbiol. 113(1), 47-53. 


\section{The Produce Contamination Problem: Causes and Solutions}

Edited by

Gerald M. Sapers

USDA, Agricultural Research Service, Retired,

Wyndmoor, PA, USA

Ethan B. Solomon

DuPont Chemical Solutions Enterprise

Experimental Station Laboratory, Wilmington, DE, USA

\section{Karl R. Matthews}

Rutgers-The State University of New Jersey

Department of Food Science, New Brunswick, NI, USA

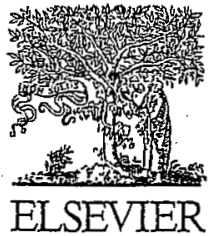

AMSTERDAM • BOSTON • HEIDELBERG - LONDON

NEW YORK • OXFORD • PARIS • SAN DIEGO

SAN FRANCISCO • SINGAPORE • SYDNEY • TOKYO

Academic Press is an imprint of Elsevier

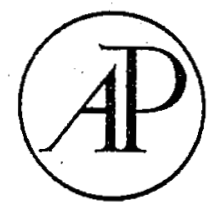

